\title{
LAS ENFERMEDADES DE LOS ojos en el Perú Prehispánico
}

\author{
Eye Diseases in Prehispanic Peru
}

\author{
Emiliano Paico-Vílchez ${ }^{1}$ y Emiliano Paico-Zumaeta ${ }^{2}$
}

\section{RESUMEN}

Los autores, después de escrudiñar en la cerámica preincaica y en las crónicas de la conquista, describen algunas de las enfermedades de los ojos que padecieron los aborígenes peruanos y cómo las curaban. Hacen saber que la conjuntivitis era la afección más frecuente y que la ceguera la más grave. Consideran que dar a conocer estos males oculares en el Perú prehispánico es un medio para fortalecer nuestra identidad nacional.

Palabras claves: Enfermedades de los ojos, ceramios, prehispánico, crónicas, cronistas del Perú.

\section{Abstract}

The authors, after scrutinizing in pre-Inca pottery and the chronicles of conquest, describe some of the eye diseases suffered by Peruvian Aboriginal people and how they cured them. They make it known that conjunctivitis was the most common condition and that blindness was the most severe. They believe that publicize these eye diseases of pre-Hispanic Peru is a means of strengthening our national identity.

Keywords: Eye diseases, pottery, pre-Hispanic, chronicles, chroniclers of Peru.

1 Cirujano pediátrico. Universidad Privada Antenor Orrego. Ex jefe del Servicio de Cirugía Pediátrica y del Servicio de Especialidades Quirúrgicas del Hospital Belén de Trujillo.

2 Estudiante de la Facultad de Ciencias de la Comunicación de la Universidad Privada Antenor Orrego.

\section{INTRODUCCIÓN}

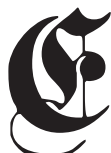
l curar las enfermedades de los ojos fue una práctica médica que han realizado todas las culturas antiguas del mundo y las antiguas peruanas no han sido exentas a ello. Práctica que nació por la necesidad de querer ver con nitidez y sin dolor cuando alguna afección oftalmológica lo impedía.

Las primeras revelaciones de las enfermedades delos ojos en el Perú prehispánico seencuentran en el valioso legado que nos han dejado los ceramistas de las culturas pre incaicas en sus preciosas y admiradas obras, especialmente de la cultura mochica.

La cultura mochica o moche se desarrolló en el valle del río Moche (actual provincia de Trujillo, La Libertad) desde finales del siglo I hasta el siglo VIII d.C., momento en que se produjo su colapso. Se extendió en la costa del Perú a lo largo del Océano Pacífico, desde el valle del rio Piura, considerado como el límite norte, hasta el valle del rio Nepeña al sur, y al este delimitada por la cordillera Andina.

Ya en los siglos XVI y XVII, los cronistas de la conquista, tanto los peninsulares como los de sangre indígena, nos informan con cierto lujo de detalles algunas de las enfermedades de los 
ojos que padecieron los aborígenes peruanos y cómo los médicos incásicos curaban esas afecciones.

Siendo las enfermedades de los ojos en el Perú prehispánico un tema médico poco trabajado por la historiografía médica peruana, los autores del presente artículo se propusieron, en primer lugar, identificar los ceramios, principalmente mochicas, que representan individuos con enfermedades de los ojos; y en segundo lugar, no por esto menos importante, escrudiñar los escritos de los cronistas de la conquista con el propósito no solo de dar a conocer la práctica de los aborígenes peruanos sino también como un medio para fortalecer nuestra identidad nacional.

\section{Cerámica y enfermedades de los ojos}

Si bien es cierto que los aborígenes del Perú no dominaron la trasmisión del pensamiento mediante la escritura alfabética que nos permitiera conocer la medicina que practicaron y los aspectos concernientes a ella, como el tipo de enfermedades que padecieron, también es cierto que este gran problema lo superaron con gransabiduríaal representarsusideasdemanera concreta en dibujos y, fundamentalmente, en la representación figurativa de la cerámica escultural. ${ }^{1}$ La capacidad de representación de las enfermedades que tuvieron los ceramistas indígenas es verdaderamente notable $\mathrm{y}$ asombrosa por el grado de realismo que presentan.

En relación a la cerámica que contribuye al conocimiento de la medicina, es la mochica la que notablemente destaca, pues en esta se encuentran las piezas más perfectas desde el punto de vista anatómico y artístico. Los eximios ceramistas mochicas han plasmado espléndidamente en sus obras a médicos, enfermos, enfermedades, técnicas de diagnóstico, métodos de curación, y muchos otros aspectos de la medicina en un considerable número de ceramios. Las representaciones fueron hechas de una manera tan natural y realista que nos permite hacer meticulosos estudios y, en consecuencia, sacar conclusiones de la medicina que se practicó en aquellas épocas.

Las imágenes de los ceramios muestran características o peculiaridades que corresponden a reconocidas entidades patológicas que se evidencian en los rostros y en los cuerpos de los enfermos representados, permitiéndonos realizar el diagnóstico con el rigor científico de la medicina contemporánea. De ahí que a los ceramios se les pueden considerar como páginas sueltas de un voluminoso libro de la historia de la medicina del Perú prehispánico, nos dice Pedro Weis. ${ }^{2}$

En mérito a lo mencionado se puede afirmar que la cerámica constituye una fuente esencial que permite conocer las enfermedades de los ojos que adolecieron los aborígenes peruanos, como las que se evidencian en las figuras de los ceramios que en este artículo se presentan (conjuntivitis, cataratas, pterigion, ceguera, exoftalmos traumatismos, tumores, etc.); y, como también algunas de las cuales fueron corroboradas por los cronistas de laconquista.

\section{ENFERMEDADES DE LOS OJOS}

Según el pensamiento del aborigen peruano, las enfermedades eran consideradas castigos enviados por alguna deidad, casi siempre por haber trasgredido una ley religiosa; o, también eran causadas por la acción maléfica de otros hombres con poderes sobrenaturales. Las formas más frecuentes de adquirir la enfermedad eran: el castigo divino, la introducción de un objeto en el cuerpo (una espina, un hueso, una flecha o un dardo), 
la posesión por un espíritu, la pérdida del alma, entre otras. Aún las enfermedades traumáticas como las heridas de guerra, accidentes, mordeduras de animales, así como las complicaciones del embarazo o del parto, tenían origen sobrenatural.

Cuando enfermaba el Inca, su causa se atribuía a faltas graves cometidas por sus súbditos, pues el Inca por ser considerado hijo del sol no podía cometer pecado ni infringir mandato alguno, y en su enfermedad también enfermaba el Sol, se debilitaba y como fuente suprema de vida acarreaba entonces múltiples peligros a la comunidad. $^{3}$

El tratamiento de las enfermedades se enfocaba a alejar la causa por medio de invocaciones o rezos a los dioses o determinado dios. Pero, la intuición natural de los médicos aborígenes era que el dios por sí mismo no siempre respondía a las invocaciones realizadas, así que a las invocaciones o rezos se les añadían algunos medicamentos que se extraían de los tres reinos de la naturaleza, especialmente del vegetal, para combatir los síntomas. ${ }^{4}$

Los medicamentos eran derivados de la observación empírica racional; es decir, los médicos aborígenes recurrían a las hierbas cuyas eficacias habían sido comprobadas con anterioridad. También recurrían a la práctica de un acto quirúrgico.

La literatura española de aquella época permite conocer el gran respeto y admiración que tuvieron los cronistas ibéricos por los médicos aborígenes. Por ejemplo, el padre Bernabé Cobo expresa que "En lo que eran expertos es en curar heridas, para lo cual conocían hierbas extraordinarias y de gran virtud." ${ }^{5}$ El padre José de Acosta reconoce también tal superioridad cuando escribe: "Aún muchos años después de la conquista, los indios tenían por tales conocimientos a los médicos (españoles) de profesión." 6

A juzgar por lo que se observa en numerosos ceramios de las antiguas culturas peruanas, y por la información que nos brindan los cronistas de la conquista, se puede manifestar que las enfermedades de los ojos existieron con cierta frecuencia entre los habitantes del antiguo Perú.

Posiblemente la más frecuente y la más conocida de las enfermedades de los ojos del Perú prehispánico fue la sufrida por el séptimo Inca Yahuar Huacac, cuando aún era niño, afección que motivó que su padre, el soberano Inca Roca, convocara a todos los médicos del Tahuantinsuyo para curar el mal que agobiaba a su hijo primogénito. ${ }^{7}$ Las interpretaciones modernas refieren que la enfermedad del niño Yahuar Huacac fue una conjuntivitis. 89

Por otra parte, al analizar los numerosos ceramios que retratan ciegos, los mismos que fueron confeccionados espléndidamente con una veracidad admirable, se puede decir que la afección oftalmológica más grave fue la ceguera y probablemente una de las más frecuentes.

Algunos cronistas, refiriéndose a las afecciones de los ojos, nos refieren de una enfermedad aguda que era endémica en el valle de Piura y que, según lo que en esa época se decía, era ocasionada por los vientos y las arenas del verano y por la humedad del invierno. Lavorería, como otros autores, cree que la enfermedad era la conjuntivitis que es muy frecuente en esa población. ${ }^{10}$

El cronista Agustín de Zárate manifiesta que "Alli ay una enfermedad natural de la tierra que da en los ojos á los más que por allí pasan". ${ }^{11}$ Antonio 
de Herrera, refiriéndose a esta enfermedad anota lo siguiente: "es algo enferma (Piura) en especial de los ojos por los grandes vientos $i$ polvaredas del verano $i$ grandes humedades del invierno." 12

Un medicamento que los aborígenes del antiguo Perú empleaban para curar algunas enfermedades de los ojos era la carne fresca de vicuña, la que se aplicaba sobre las partes inflamadas. Refiriéndose a ella, el padre Cobo dice: "Es una carne de complexión fría, la cual, aplicada sobre los ojos y demás miembros del cuerpo inflamados los deshincha y los desinflama". ${ }^{5}$

Por su parte, al padre Acosta le sobrevino un intenso dolor en los ojos que fue curado en poco tiempo por una indígena quien le aplicó en los ojos carne cruda fresca de vicuña. ${ }^{6} \mathrm{El}$ religioso narra la curación de la siguiente manera: "Caminando por la sierra del Perú llegué una tarde a un tambo con un terrible dolor de ojos que me parecía que querían saltar. Accidente que suele acaecer al pasar por donde hay mucha nieve y mirarla. Estando sentado con mucho dolor que creía perder la razón; llegó una india y me dijo: Padre, ponte esto en los ojos y estarás bien. Era un trozo de carne fresca y sangrante de vicuña recién muerta. Y poniéndome esa medicina me aplicó el dolor, y dentro de muy breve tiempo se me quitó el dolor de todo, que no lo sentí más."

En lo que concierne a los medicamentos de origen vegetal que usaban para tratar las enfermedades de los ojos, los cronistas mencionan algunos de ellos. Cobo indica que el cocimiento de choclla con llantén se empleaba para "curar las llagas de los ojos" (probablemente conjuntivitis purulenta o queratitis); que el cocimiento de la Acana cura "las nubes" (posiblemente cataratas o pterigion); y, que el cocimiento de una piedra verde que llamaban Coravari, "quita y gasta las nubes, clarifica la vista y detiene las lágrimas." (5)
Garcilaso de la Vega, no solo hace referencia al matecllu si no que lo alaba diciendo que es uno de los medicamentos más empleado por su gran eficacia. De esta planta el cronista escribe lo siguiente: "el zumo echado la primera noche en los ojos enfermos, y mascada puesta como emplastro en los párpados y encima una venda para que no se caiga la yerba, gasta en una noche cualquier nube que los ojos tengan y mitiga cualquier dolor o accidente que sientan." 13 Garcilaso refiere un caso de curación efectuado por él mismo empleando matecllu. "Yo se la puse a un muchacho que tenía el ojo para saltarle del casco; estaba inflamado como un pimiento, sin diferenciarse lo blanco ni prieto del ojo, sino hecho una carne, y lo tenía ya medio caído sobre el carrillo, y la primera noche que le puse la yerba se restituyó el ojo a su lugar, y la segunda noche quedó del todo sano y bueno."

El molle también fue utilizado para las enfermedades de los ojos. El religioso jesuita Antonio de la Calancha manifiesta que "la leche del molle deshace las nubes de los ojos." 14

Es importante mencionar que, a los ciegos como otros discapacitados, el Estado Incaico y la sociedad los protegían. Al respecto, el cronista Guamán Poma de Ayala nos cuenta que, en Cusco, los gobernantes incas reunían en un mismo barrio a ciegos, jorobados, mudos y a los que tenían la nariz hendida (labio leporino), obligándoles a casarse entre los que tenían el mismo defecto o malformación con el objetivo que no se extinguiesen. ${ }^{13}$

Respecto al trabajo que desempeñaban los ciegos, Garcilaso de la Vega anota lo siguiente: "el oficio propio de los ciegos era limpiar el algodón de la semilla o grano que tiene dentro en sí, y desgranar el maíz de las mazorcas en que cría." 13

Finalmente, según el historiador Juan Lastres el cirujano (sirkak) del antiguo Perú demostró destreza manual y cierta habilidad 
técnica cuando realizaba sus intervenciones quirúrgicas. ${ }^{16}$ La habilidad de los cirujanos aborígenes también fue alabada por Roy Moddie, quien con mucho convencimiento

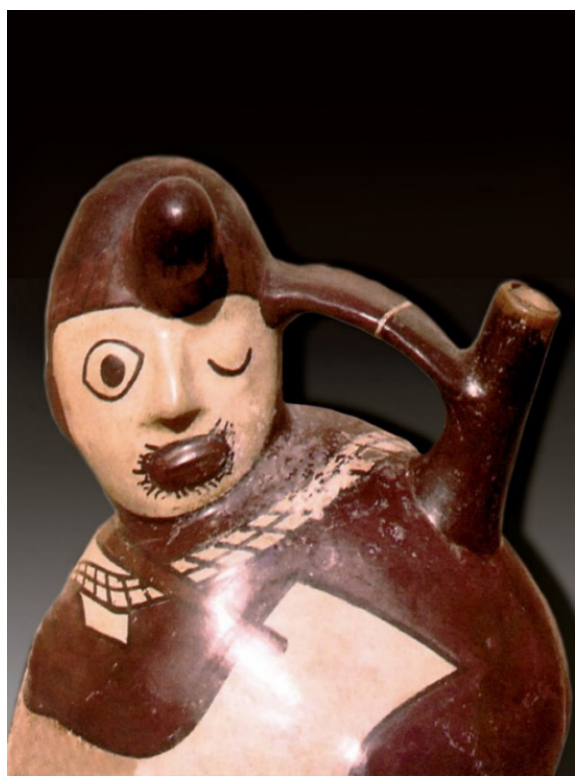

Rostro de un individuo con blefaroptosis o ptosis palpebral izquierda. Cerámica nazca - Museo Nacional de Arqueología, Antropología e Historia (MNAAHP).

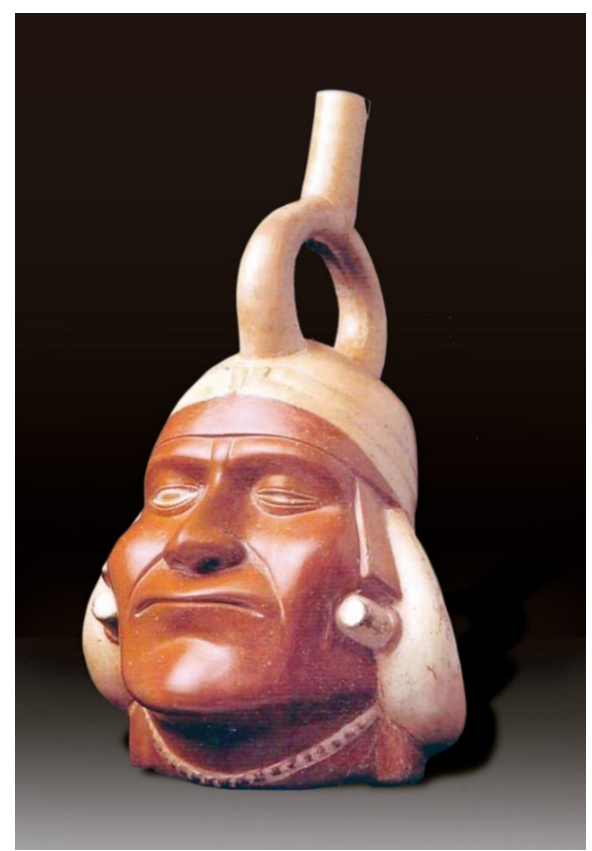

Rostro de un varón con blefaroptosis o ptosis palpebral izquierda. Cerámica mochica, MNAAHP. afirmó que "a juzgar por el éxito de sus operaciones, no existe otra raza que produjera mejores cirujanos como la peruana." 17

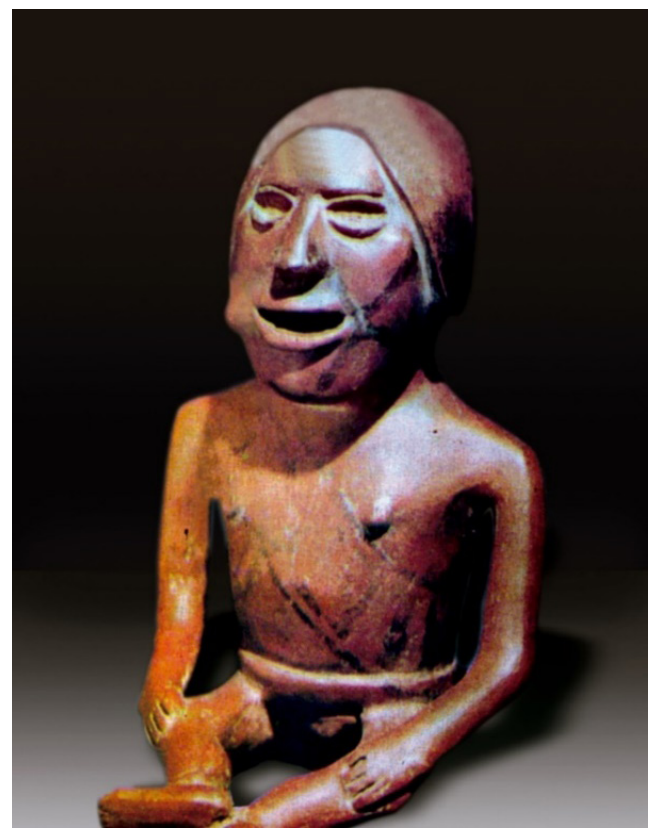

"Chacchador" de coca con blefaritis y ectropión bilateral. Además, presenta signos de hipertiroidismo o desnutrición. Cerámica mochica, MNAAHP.

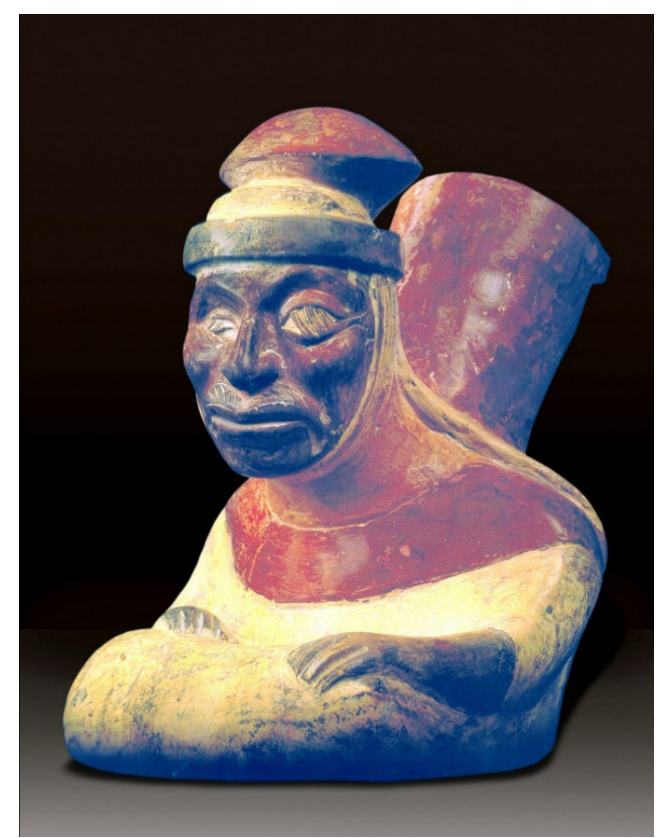

Individuo mochica con conjuntivitis bilateral, probablemente de etiología gonocócica. Cerámica mochica, MNAAHP. 


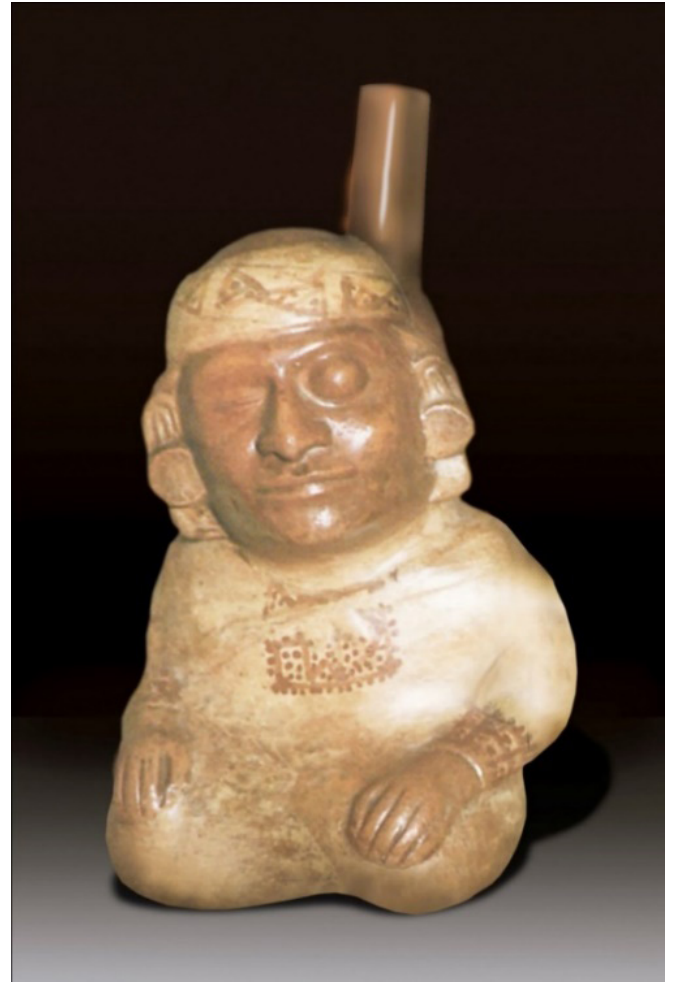

Varón con un tumor en el globo ocular izquierdo. Cerámica mochica, MNAAHP.

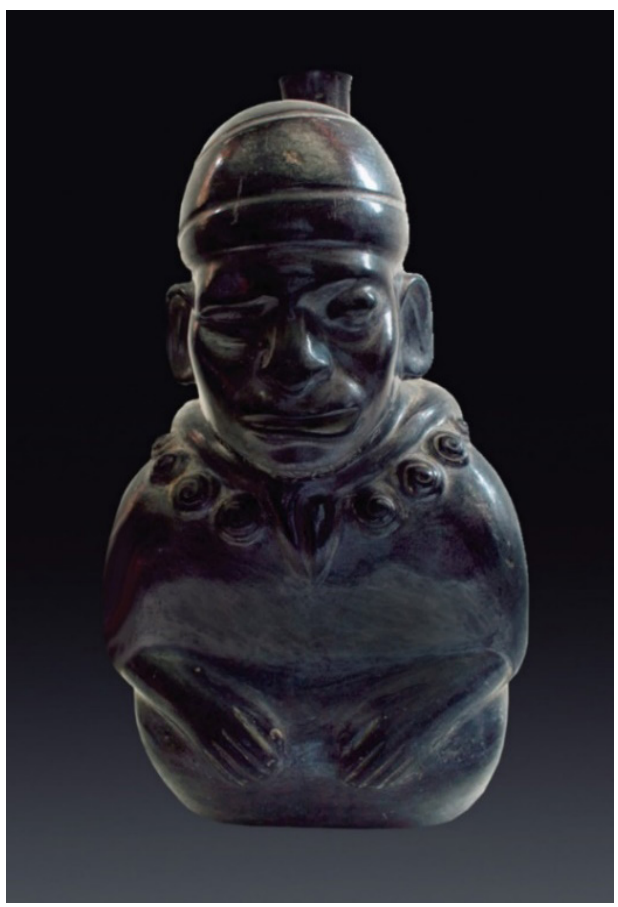

Enfermo de exoftalmos izquierdo y parálisis facial. Cerámica chimú, MNAAHP.

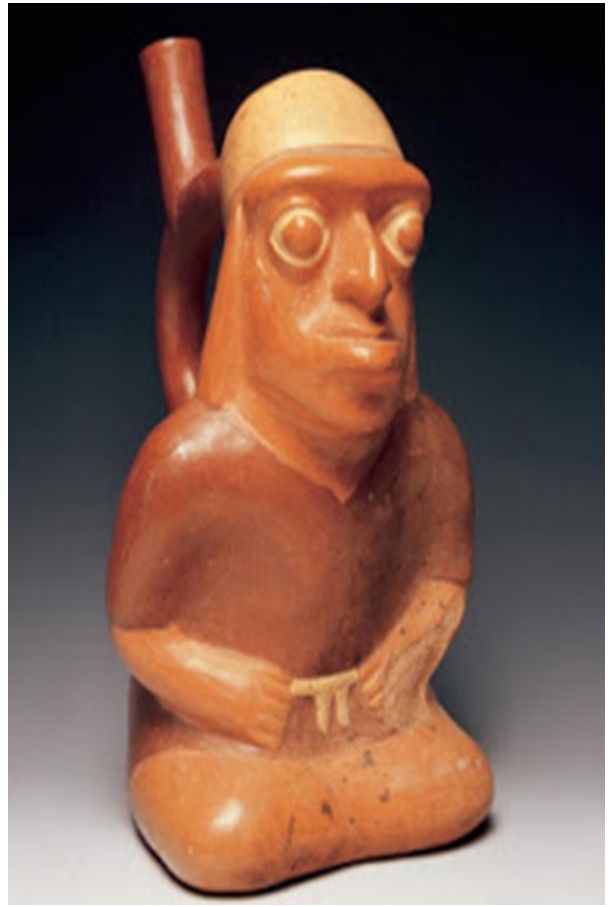

Individuo con exoftalmos bilateral como componente del síndrome de Crouzon. Cerámica mochica, MNAAHP.

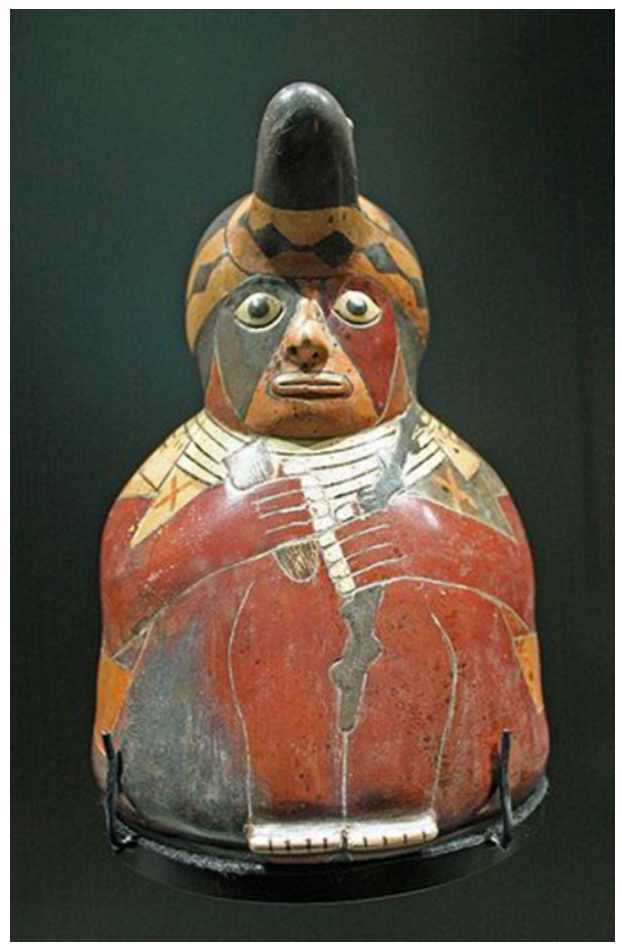

Representación de un individuo con exoftalmos. Cerámica nazca, Collection Janssen. 


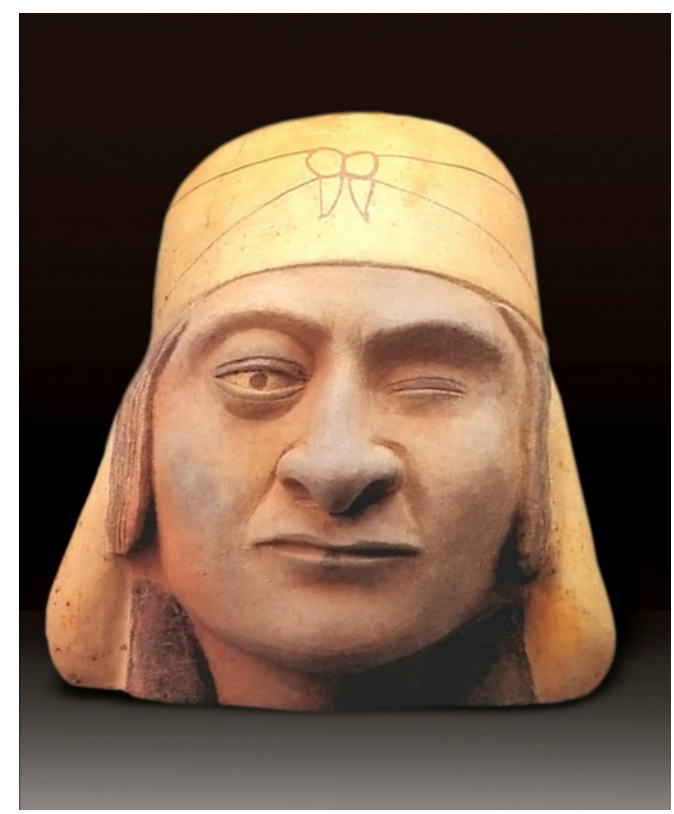

Rostro de un individuo quien ha sufrido enucleación del globo ocular izquierdo. Cerámica mochica Museo de Arqueología, Antropología e Historia de la Universidad Nacional de Trujillo (MAAHUNT).

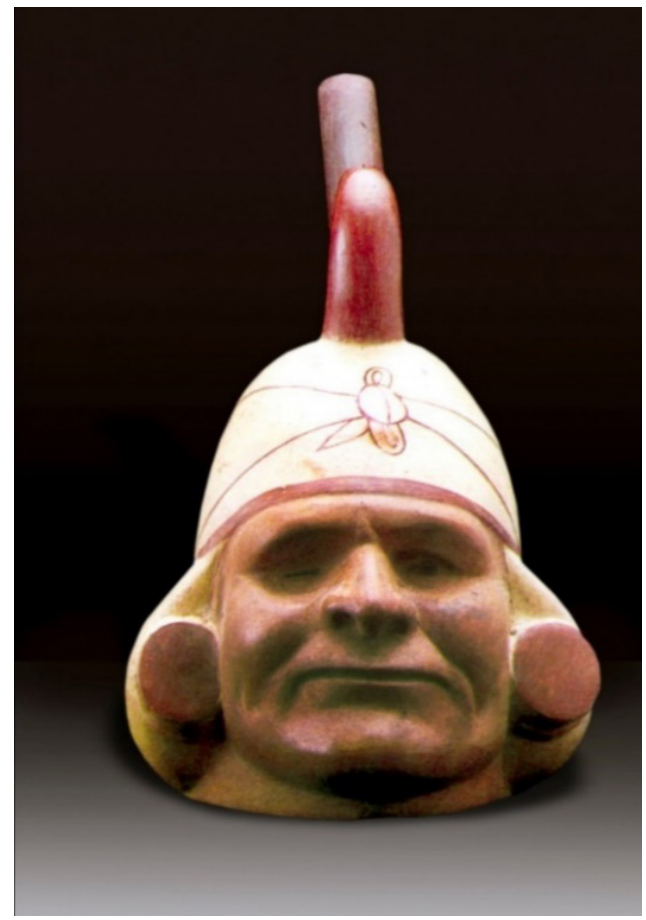

Rostro de un individuo quien ha sufrido enucleación del globo ocular derecho. Cerámica mochica - Museo de Arqueología Rafael Larco Herrera (MARLH).

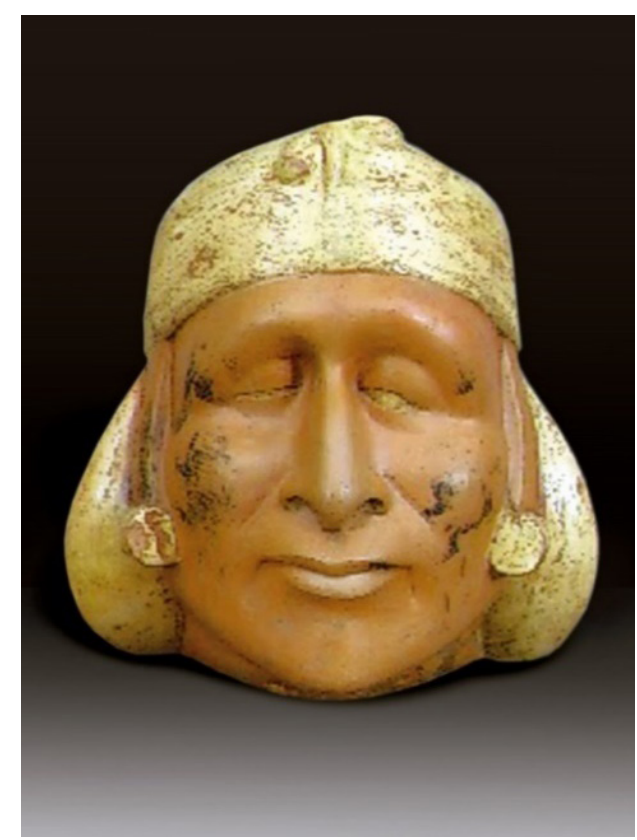

Rostro de un personaje con anoftalmia derecha. Cerámica mochica, MNAAHP.

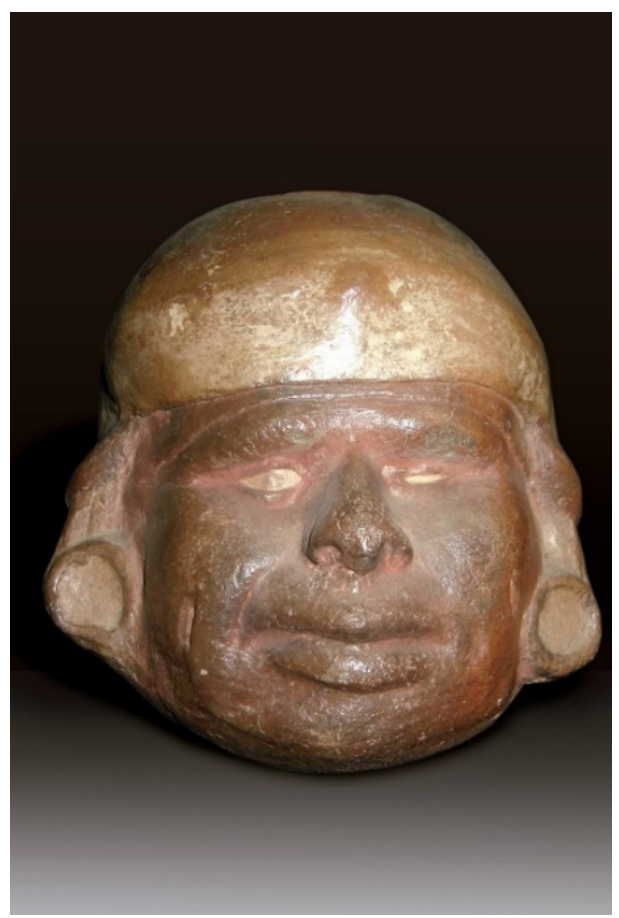

Rostro de un individuo con catarata derecha y ceguera del ojo izquierdo. Cerámica mochica, MAAHUNT. 


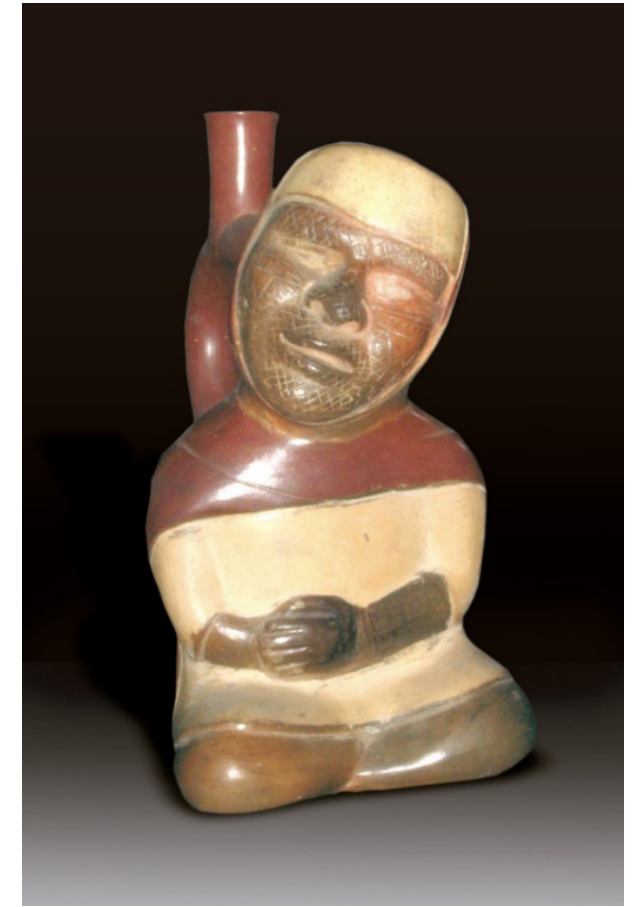

Personaje con catarata izquierda, ceguera del ojo derecho y rostro con escarificaciones. Cerámica Mochica, Museo Arqueológico Cassinelli (MAC).

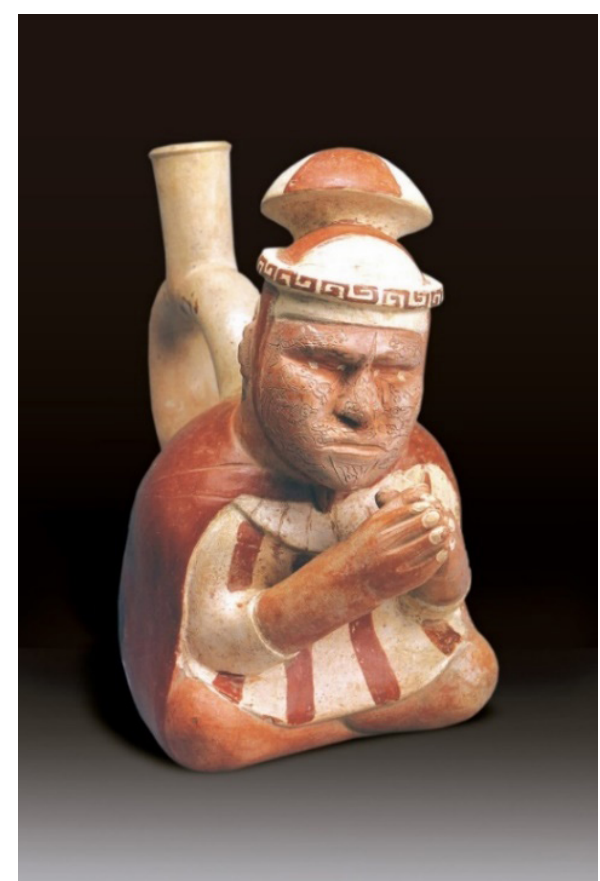

Personaje con ceguera bilateral y rostro con escarificaciones. Cerámica mochica, MNAAHP.

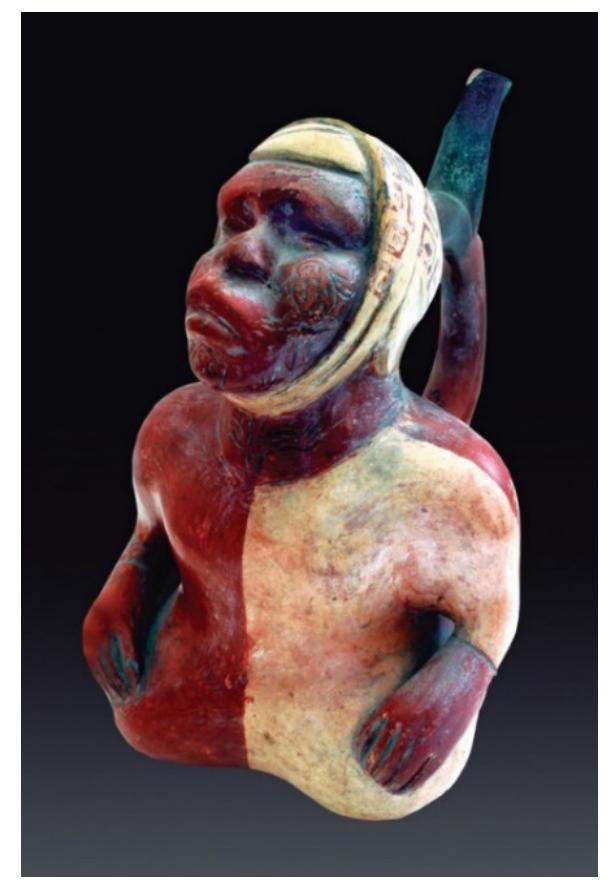

Representación de un ciego con escarificaciones. También presenta edema en la cara, especialmente en el labio superior. Cerámica mochica, MNAAHP.

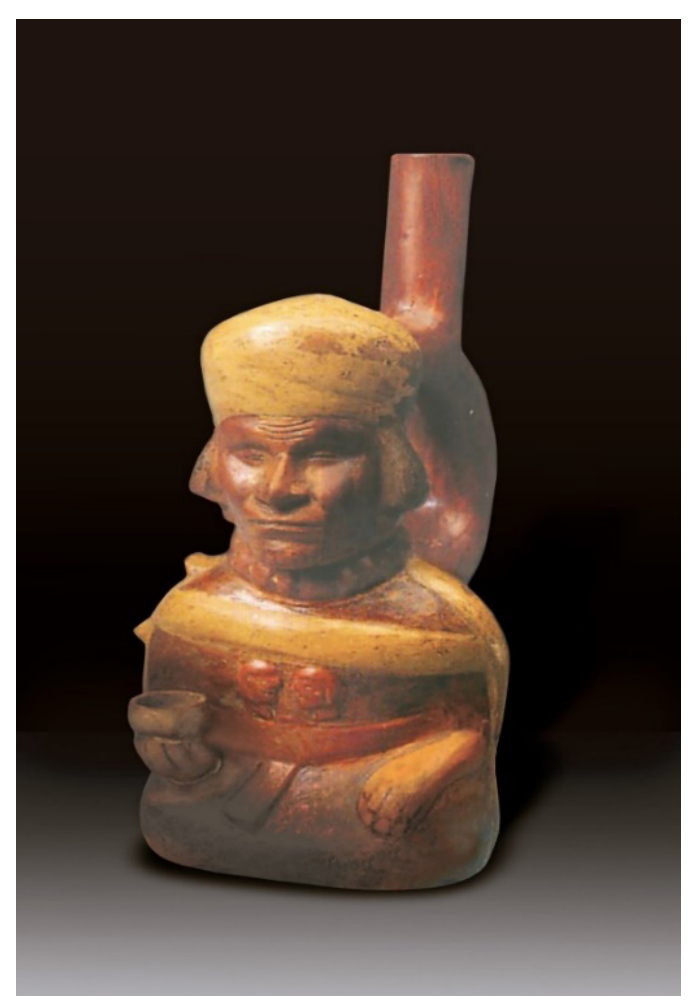

Ceramio que representa a un ciego que sostiene con su mano derecha un recipiente. Cerámica mochica, MAC. 


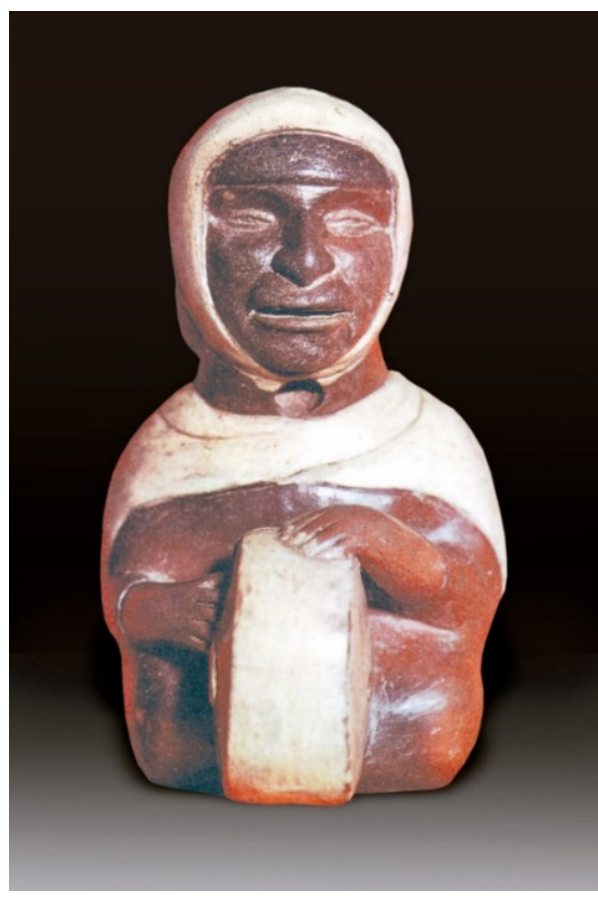

Representación de un ciego tocando su pomatinya o tamborcito Cerámica mochica - MNAAHP.

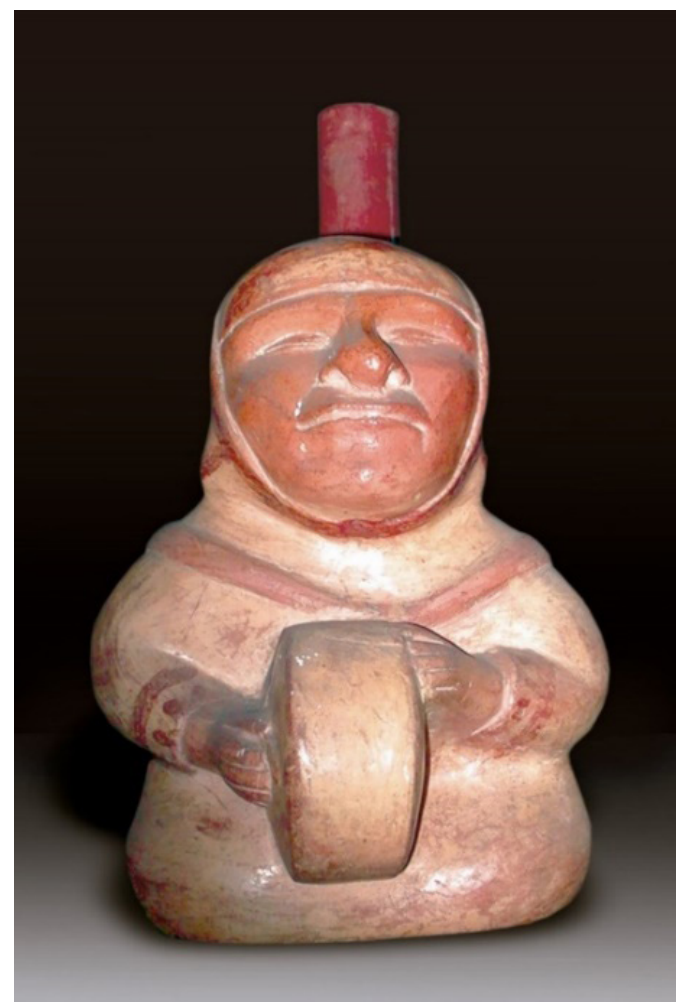

Representación de un ciego tocando su pomatinya o tamborcito. Cerámica Mochica, MAC.

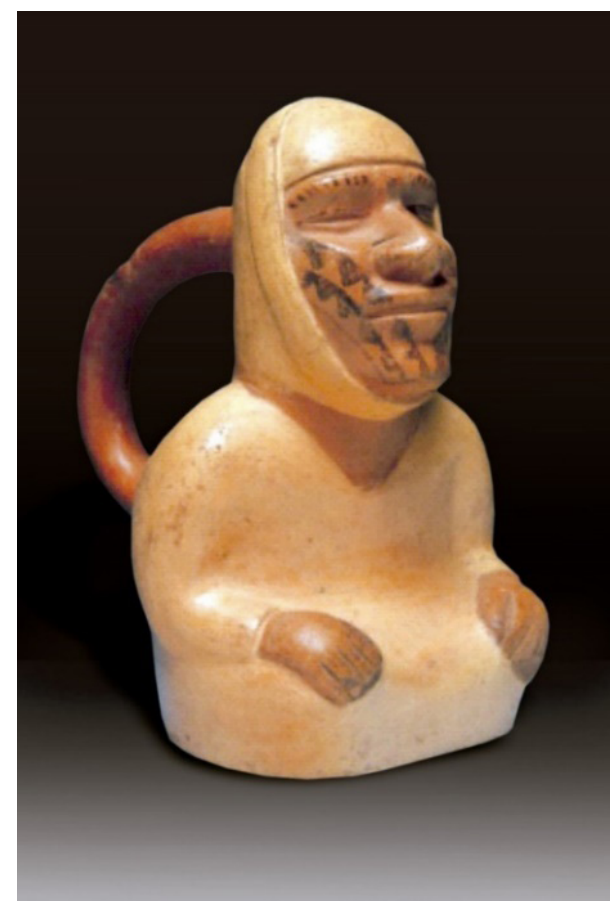

Varón con el rostro tatuado que presenta ceguera bilateral producida probablemente por una conjuntivitis recidivante. Cerámica mochica, MARLH.

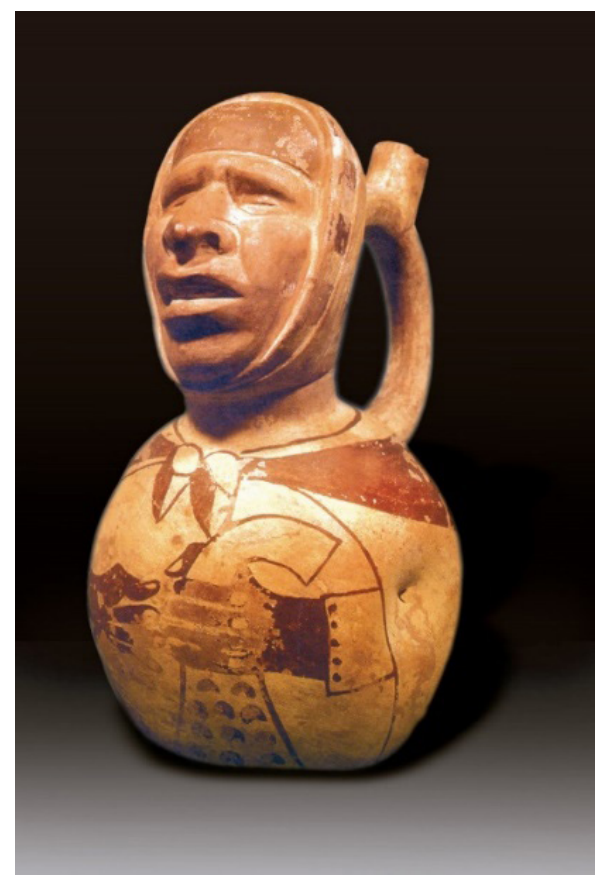

Individuo con ceguera bilateral, ocasionada posiblemente por conjuntivitis recidivada. Cerámica mochica, MNAAHP. 


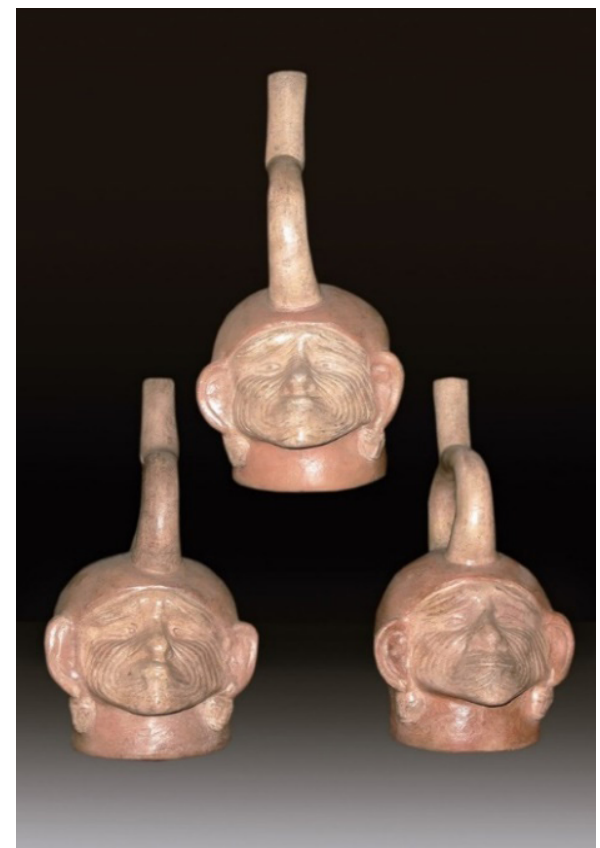

Rostros que representan la evolución de la ceguera en una misma persona por la edad muy avanzada. Cerámica mochica, MAC

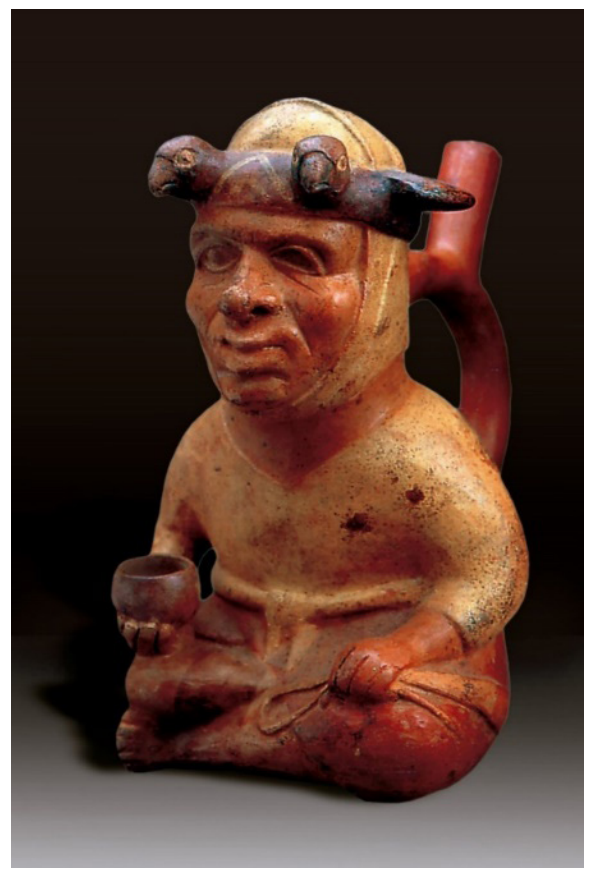

Hombre que sufrió traumatismo ocular izquierdo con enucleación del ojo y retracción del parpado inferior. Cerámica mochica, MNAAHP.

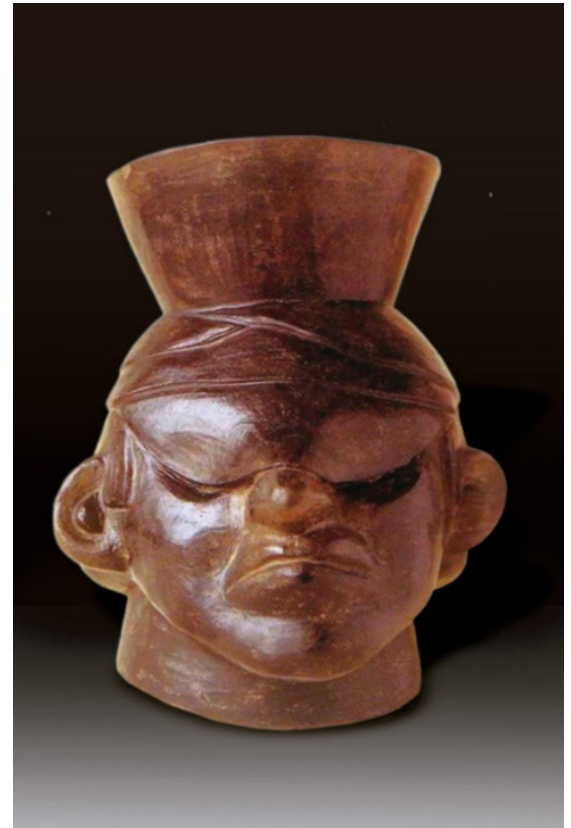

Rostro de un individuo con traumatismo facial Obsérvese el gran edema de los párpados superiores, equimosis en los párpados inferiores (signo del mapache) y deformación de la nariz. Cerámica mochica. MNAAHP.

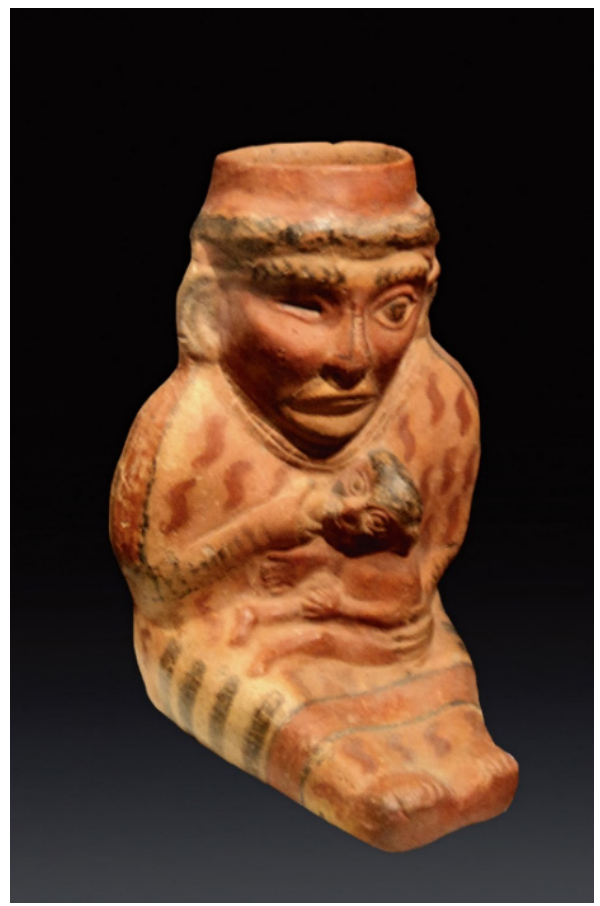

Escena de una madre tuerta dando de lactar a su hijo. Cerámica mochica. Colección Juan Julio Rosales Olano. 


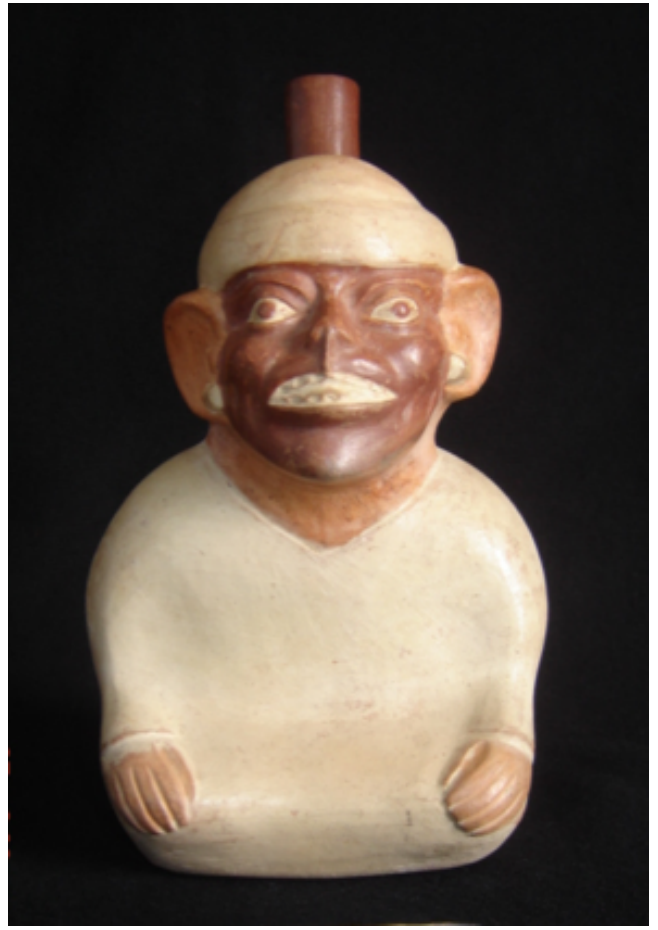

Individuo con estrabismo divergente, macrotia y macrostomia. Cerámica mochica, MAVLH.

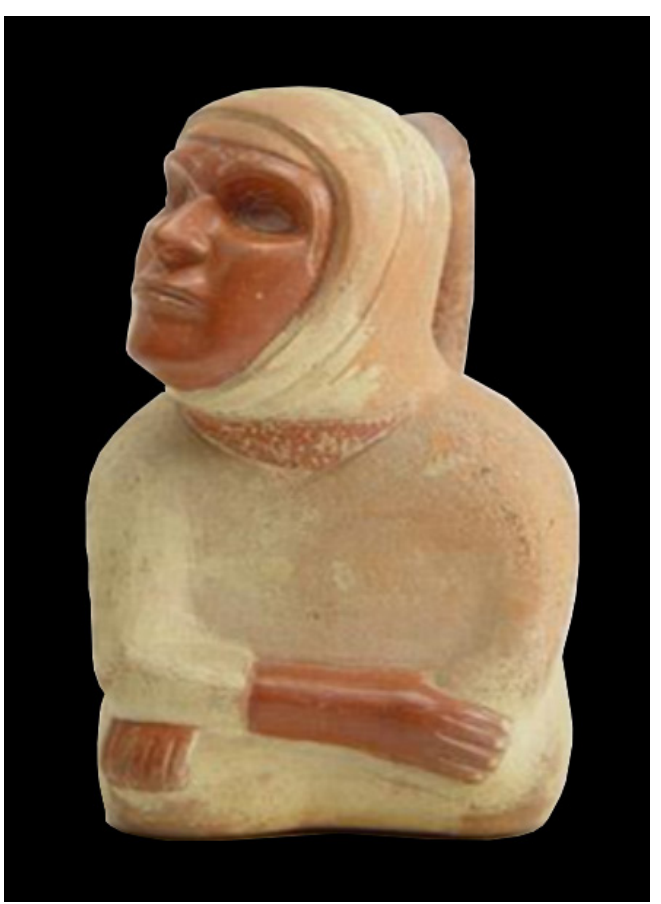

Representación de un varón con catarata bilateral. Cerámica mochica, MARLH.

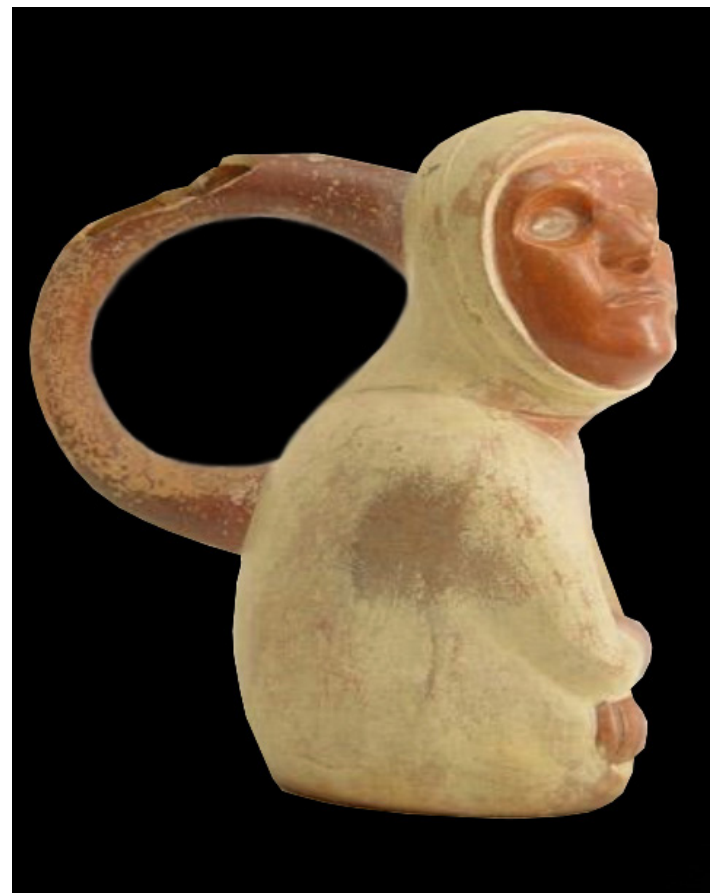

Ceramio anterior visto de otro perfil. Varón con catarata bilateral. Cerámica mochica, MARLH:

\section{REFERENCIAS BibLIOGRÁFICAS}

1. García Cáceres, Uriel. La salud en el antiguo Perú. En: Enciclopedia Temática del Perú, Lima, Ed. El Comercio, 2006.

2. Weiss, Pedro. Paleopatología americana. Boletín de Lima. 1984;6(33): 17-52.

3. Madrigal Lomba R, López Quintana MC. La Medicina en el Perú Prehispánico. 2008; 30 (5). URL disponible en URL:http: / / www.revmatanzas.sld.cu/revista\%20médica / ano\%202008 / vol5\%202008/tema16.htm

4. Pardal Ramón. Medicina Aborigen Americana. Segunda Edición. Sevilla: Editorial Renacimiento;1968.

6. Cobo, Bernabé. Historia del Nuevo Mundo (1653). Madrid: Editorial Atlas;1956.

7. Acosta, José de. Historia Natural y Moral de las Indias (1590). Madrid: Consejo Superior de Investigaciones Científicas; 2008.

8. Pachacuti, Juan de Santa Cruz. Relación de Antigüedades de este Reino del Perú (1613). Lima: Edit. Fondo de Cultura Económica, Lima, 1995.

9. Valdizán, Hermilio. Historia de la Medicina Peruana. Lima: Ediciones Hora del Hombre; 1944.

10. Paico-Vílchez, Emiliano: Armonía y Plenitud del Ser: La Cirugía en el Antiguo Perú. Trujillo (Perú), Fondo Editorial de la Universidad Privada Antenor Orrego, 1913.

11. Lavorería, Daniel Eduardo. El arte de curar entre los antiguos peruanos. Lima: Imprenta y Librería de San Pedro; 1901.

12. Zárate, Agustín de. Historia del Descubrimiento y Conquista del Perú con las Cosas Naturales que Señaladamente allí se hallan y los Sucesos que ha habido. Madrid; 1923. 
13. Herrera, A. Historia general de los hechos de los castellanos en las islas y Tierra Firme del Mar Océano. Madrid, 1615.

14. De la Vega, Garcilaso. Comentarios Reales de los Incas (1603). Lima: Editorial Fondo de Cultura Económica; 1991.

15. Calancha, Fray Antonio de la. Crónica Moralizadora de la Orden San Agustín en el Perú (1653). Tomo II. Lima; 1976.

16. Guamán Poma de Ayala, Felipe: Nueva Crónica y Buen Gobierno (1615). Tomo I. Lima: Editorial Fondo de Cultura Económica; 2005.

17. Lastres, Juan B. La Historia de la Medicina: La Medicina Incaica. Tomo I, Lima: Edit. UNMSM, Imprenta Santa María; 1951.
18. Moddie, Roy. The diseases of the ancient Peruvians and some account of heir surgical practices. Surgical Clinics of Chicago. 1920;4:211-31.

\section{CORRESPONDENCIA: Emiliano Paico Vílchez epaicov@gmail.com}

Fecha de recepción: 11-11-2020.

Fecha de aceptación: 20-01-2021.

Conflicto de interés: ninguno, según el autor.

Financiamiento: por el autor. 